\title{
A Deeper Look Into Political Instability and Economic Growth: Case Study and Empirical Analysis on a Selection of Countries
}

\author{
Fawzeya Ahmed Abdelhameed ${ }^{1,2} \&$ Abeer M. Rashdan $^{2}$ \\ ${ }^{1}$ Economic Department, Faculty of Economics and Political Sciences, Cairo University, Egypt \\ ${ }^{2}$ Future University, Egypt \\ Correspondence: Fawzeya Ahmed Abdelhameed, Economic Department, Faculty of Economics and Political \\ Sciences, Cairo University, Egypt. \\ Received: February 18, 2021 \\ Accepted: March 30, 2021 \\ Online Published: April 28, 2021 \\ doi:10.5430/rwe.v12n3p18 \\ URL: https://doi.org/10.5430/rwe.v12n3p18
}

\begin{abstract}
The purpose of the study is to investigate the nature of the relationship between political instability and economic growth in a selection of countries witnessing political instability including Egypt, Tunisia, Algeria, Sudan, Brazil, Turkey and Indonesia, during the era (1994-2019). Research methods include country case study analysis of macroeconomic indicators and an empirical analysis, to determine whether political instability plays a significant and important role in the different dimensions of economic growth measured by the Human Development Index, Gross Domestic Product GDP, and gross fixed capital formation. Findings prove a significant negative relationship between political instability and economic growth statistically and economically. Recommendations highlight the importance of transmission channels that enforce the significant negative relationship between political instability and economic development.
\end{abstract}

Keywords: economic growth, political instability, human capital, investment

JEL classification: 040, 057, D71

\section{Introduction}

Political stability plays a vital role in economic development, driving economic growth. Recently, the United Nations (2015) considered political instability as a major national weakness in many developing countries and affects their productivity and growth. (Sweidan, 2016) The volatile political climate hinders the pace of economic development in any country. Gupta (1990) put it this way: "Without political stability people cannot trust themselves in their economy, and when faith is lacking, people find safer places to invest their money, rather than investing in the economy". Attention to political instability and growth nexus raised many questions regarding the definition of political instability, what proxy can measure it and causal analysis between the two variables.

Inevitably, economic growth and political instability are closely linked. On one hand, the uncertainties associated with an unstable political environment can undermine investment and economic development. On the other hand, economic mismanagement can wreak havoc on the government and on political problems. Political instability is highly expected to reduce the horizons of policymakers leading to the overriding of macroeconomic short-term policies. It can also lead to several policy changes, creating instability and thus, adversely affecting macroeconomic performance. Given its detrimental effects on economic performance the level at which political instability is prevalent in all countries.

This link between political instability and economic growth has attracted the attention of economists for the past 40 years. Several results have shown that political instability is detrimental to economic growth (Jong-APin 2009; Alesina et al. 1996). Also, political instability keeps physical finances (Aisen and Veiga 2013) and can lead to declining investments (Alesina and Perotti 1996; Barro 1991; Rudrik 1989; Schneider and Frey 1985).

This paper aims to achieve a more appropriate economic - political situation in these countries, examining the impact of political instability on economic growth in seven countries (Egypt, Tunisia, Algeria, Sudan, Turkey, Brazil, and Indonesia). These countries have experienced both political and economic changes over the past few decades. Research analyses the effects of political instability on growth. According to the literature, we find that political instability drastically reduces economic growth, statistically and economically. But it adds to the current literature by 
largely determining the importance of the transmission channels for o political instability and how it affect the economic growth. This paper contributes to a better and clear understanding of how politics affects economic performance in these seven countries which have common characteristics as they are developing, middle income or low-income countries. The study is organized as follows. Section two; shows economic growth and determining political instability. Section Three; describes the profile of selected countries; Section Four; develops data and methodology. Section five; shows the empirical results. Finally, the conclusion.

\section{Literature Review}

Economic growth and political instability are closely linked. Increasing political instability increases the chances of a change of government over time (Shahbad, 2014). On one hand, the uncertainties correlated with unstable political environment can undermine investment and economic development. On the other hand, economic mismanagement can wreak havoc on government and politics (Alesina, et al., 1992). When it comes to define the meaning Political instability it could be the tendency to change rapidly in government. Alesina et al. (1996) described political instability as "accustomed to change at the highest levels of public office, either constitutionally or unconstitutionally". Economists define political instability as a combination of fluctuations and changes in the political environment that undermine socio-economic performance (Aisen and Veiga, 2013). Political instability can lead to an unpopular decision-making process for policy makers and officials. Moreover, the definition of political instability is usually a double-edged definition. According to Carmignani (2003), the first case is about social and political unrest such as change, great violence that can result from religious and economic conflicts. Another view is about government changes that can be explained by the interaction between interest groups and voters in the elections.

\subsection{The Uni-Directional Relation From Political Instability to Economic Growth}

The link between political instability and economic growth has attracted an increasing attention over the past four decades, with many publications finding that the relationship is one-sided from political instability to economic growth. Others have found that the relationship is between the two of them is bidirectional. In many studies on the relationship between political instability and growth, they have found several possible channels for this effect. As political instability is linked to greater uncertainty about future economic policy, it is likely to have a negative effect on investment and, as a result, human capital, the performance, and economic efficiency as follows:

\subsubsection{Investment in Physical Capital}

Several results have shown that political instability is affecting economic growth through inflation and can lead to lower investment (Alesina et al. 1996; Jong-APin 2009; and Aisen and Veiga 2013). In addition, some studies have suggested that political instability often undermines direct foreign investment and could lead to higher inflation (Busse and Hefeker 2007; Alfaro et al. 2008; and Aisen and Veiga 2006).

An important contribution to political instability in economic growth is investment and capital. The possibility of a government collapse will lead to a new government with a higher tendency for tax revenues on productive sectors which could lead to flight of cash flow instead of investment and production, leading to a reduction in domestic production. (Abdelkhadir, 2017) According tp Alesina and Tabellini (1988) studied political instability by measuring its effects on cash flow and investment. The results show that changes in government tax policies increase the chances of a government collapse.

In 1992 Alesina et al., Data used for 113 countries during this period (1950-1982) found that in countries and times with high expectations of political instability, growth was very slow. They have concluded that low economic growth is not likely to increase the chances of a change of government. But whenever political instability tends to persist, since the frequent collapse of the government increases the likelihood of a further collapse. Which means a continuous period of political instability, consistent with the "Coup Trap" (Alesina et al. 1996). Barro and Lee (1994) used the same method in a sample of 116 countries at the same time and obtained the same result. Even in recent studies such as Aisen and Veiga (2013) a cross-sectional sample is used from 169 countries and Qureshi et al. (2010) on Pakistan, both studies have found a negative link between political instability and economic growth. Jong-A-Pin (2009) highlights the differences in size and significance of the various indicators of political instability in economic growth. Finding that a doubling the public protest reduces the growth rate by $1 \%$. In addition, the defined variability in actual GDP per capita growth has increased in the moderate model when the inclusion of the rotest variables. While Przeworski and Limongi (1993) summarized the results of 21 different studies examining the relationship between political instability and economic growth. Their results show that in $76 \%$ of the cases there is a negative relationship between political instability and current growth, and in $24 \%$ there was no evidence of this relationship. 
Aisen and Veiga (2013), based on a sample of 169 countries, showed the impact of political instability on the reliability of government economic policies. Finding that additional changes in cabinets reduce GDP growth by $2 \%$, due to the changing effect on both physical and human productivity. In addition, they argued that a one unit increase in the political freedom index would increase economic growth by $1 \%$ annually. Bernal-Verdugo, Furceri, and Guillaume (2013) reached the same results by using a sample of 183 countries to assess the impact of political instability on economic growth and development, they concluded that one more change in cabinet, led to a $1 \%$ decrease in GDP growth rate; however, when the MENA countries and sub-Saharan African countries were sampled, the negative impact diminished to highlight the importance of political instability in these regions. While the Granger causality test shows a negative relationship between political instability and economic growth in sub-Saharan Africa, but not consistent with MENA countries results, that was not in line with the expectations of theories (Carmignani, 2003).

\subsubsection{Economic Efficiency or Uncertainty}

The fact that a government with an uncertain future can deliberately adopt negative economic and non-economic decisions to make the situation worse in the next government. Studies of Alesina and Tabellini (1988), Alesina and Tabellini (1990), Edwards and Tabellini (1991) and Ozler and Tabellini (1991), found the effects of political instability on external debt and uncertain inflation, if the government was unsure of its survival, could engage in ineffective policies to "do evil" in the world for its successor, and therefore instability. in politics it leads to economic inefficiency. Another aspect of the argument can be presented in Murphy, Shleifer and Vishny (1991) study of the impact of rent- seeking show that a weak government threatened with loss of office will seek to please lobbies and pressure groups to sustain in position, thus leading to direct success of rent -seeking on policy decisions, which could have a negative impact on all of the community. increasing uncertainty about the future, can lead to improper resource allocation. In addition, it could reduce research and development efforts by firms and governments, leading to slower technological advances. Violence, civil unrest, and strikes, reduce working hours, productivity. (Jong-A-Pin 2009).

\subsubsection{Human Capital}

Finally, people's finances can be hampered by political instability because uncertainty about the future can lead to lower investment in education. Gyimah-Brempong and Camacho (1998) study for 18 Latin American countries However, human capital investment can cover many elements as it include education, health, nutrition and life expectancy as well as the university enrollment rate. Their results asserted the negative impact of political instability on economic growth, as well as the indirect negative impact on human capital investment.

\subsection{The Two Directional Relation of Political Instability and Economic Growth}

The study of the effects of political instability on economic growth requires tackling the problem of cohesiveness: while it is true that the high power of change in government slows growth, it is also possible that the fact that low growth increases opportunities for change in government. The effect of the growing revolution in government is likely to be felt in both democracy and dictatorship.

In democratic countries, empirical studies have shown that the high growth in previous years increases the chances of re-election in the current government: voters will not re-elect the government if they see that these people are abusing the economy. In a non-democratic way, the chances of a military coup could also decrease GDP growth rate. Lower growth can increase general dissatisfaction among the people and create incentives to engage in anti-government political action. (Londregan and Poole (1990), (1991)). On one hand, weak economic performance may lead to the collapse of a government and political instability, while political instability can slow down the country's development process, which in turn contributes to the country's failure. Also, political uncertainty undermines the ability to make reliable predictions, which have led to the formation of short-term economic policy. (Shahbad, 2014)

Many studies have found a negative link between political instability and economic growth. Often the argument in academic literature about this relationship is that the country's uncertain political situation includes uncertain government decisions about the economy, investment policies, labor supply and full productivity have a negative impact on economic growth (Rodrik, 1991). Investors who have already invested in the country can escape from this type of uncertain market. Meanwhile foreign investors who want to invest and start a business seek a secure and stable political climate in the country and can avoid countries with a high probability of government change and the collapse of the political system (Goodrich, 1992), Gupta (1990), Barro (1991), Alesina et al. (1996). 


\section{Political Economy Analysis of Selected Countries}

\subsection{Algeria}

Algeria is one of Arab developing countries that are well endowed with oil resources, Algerian economy dependence on oil exports as major source of earnings, which made economic growth more vulnerable to fluctuations according to the global oil prices. Following the slump in global oil prices since 2015 has led to deterioration in macroeconomic balances, Hydrocarbon exports amount to $95 \%$ of total exports and around two-thirds of government revenues. The growth rate falls to $0.9 \%$ in 2019 , compared to $1.4 \%$ in 2019 as it shown in figure (1). The year 2019 has witnessed political uncertainty and social unrest leading to the deceleration of economic activity. The spread of the COVID-19 virus could also lower private consumption and investment, while falling oil prices will cut into fiscal and export revenues that would aggravating the twin deficit. A protesting opposition was erupted in February 2019, demanding the president to resign, which took place in April. This political uncertainty has reduced levels of predictability in the business environment, despite this turbulence situation of the country, significant steps were taken to improve the wellbeing of people. The country in critical economic and political station due to dual shock of covid-19 and fall in oil price. However, Algeria has significantly improved its human development index from 0.666 in 2000 to 0.759 in 2018. As evident in Figure One, GDP growth reached its maximum in 2003 by achieving 7.2\%, while it reaches its lower percent at $0.9 \%$ in 2019 during the period of social unrest.

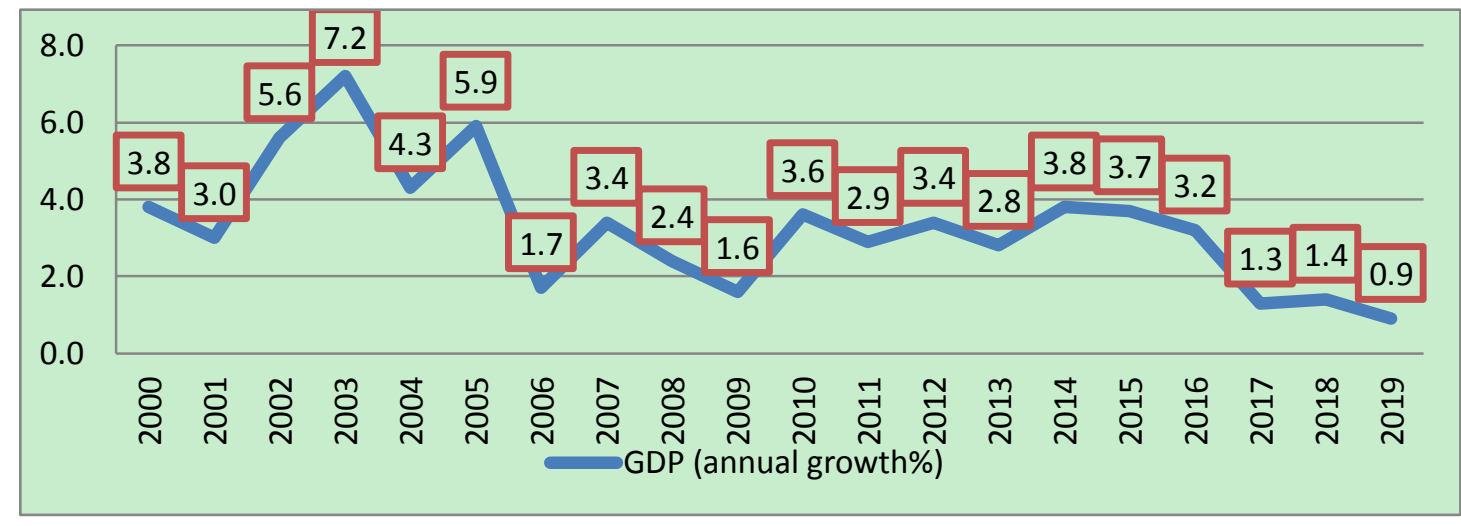

Figure 1. GDP annual growth rate in Algeria during the period (2000-2019) (\%)

Source: World development indicators, 2019.

\subsection{Tunisia}

Tunisia is one of the Arab states in the spring, a country that gained independence from France in the 1950s. Habib Bourguiba, the first father of modern-day Tunisia. Following the military coup against Bourguiba, Ben Ali's accession to power in 1987, while elections were held periodically $(1989,1994,1999,2004,2009)$, the electoral system favored the leadership of the ruling party. Tunisia has undergone economic restructuring programs established in the 1986 agreement with the International Monetary Fund and the World Bank. The reforms have succeeded in boosting economic growth in the first phase, the level of public spending on public policies remains consistently high, about 19\% in 1987-2005, people's access to health and education has increased significantly (Ben Romdhane, 2007).

While promoting the welfare of the Tunisian people, social policy was a tool of power and control in the hands of the state (Hibou, 2006). Despite all these achievements, two decades after the reform movement, the country experienced high levels of corruption, a lack of transparency and law enforcement. That made many Tunisians and foreign businessmen reluctant to invest in the country. By January 14, 2011 the revolution sparked, where the progress made in the political transition, the democratic system could not be followed by major economic change. The fragmentation of the political party system and the difficulties associated with reaching consensus on important economic changes, in addition to external issues, such as the conflict in neighbouring Libya. As shown in Figure (2) the country experienced a slowdown in economic growth after a short-term rise in 2012, reaching $1.034 \%$ in 2019 driven by the agreement in the oil and gas industry and agricultural industries. 


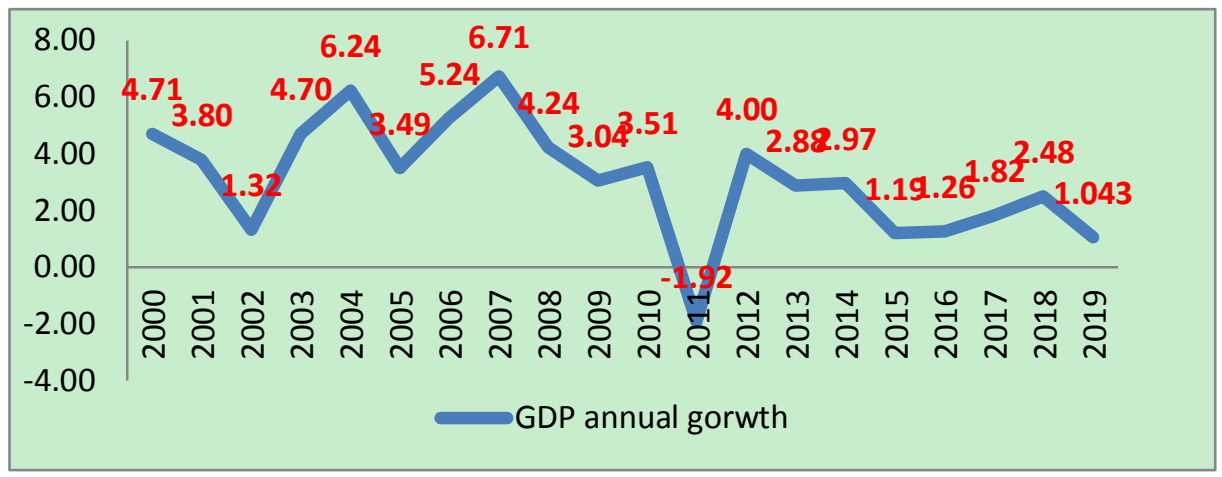

Figure 2. GDP annual growth rate in Tunisia during the period (2000-2019) (\%)

Source: World development indicators, 2019.

\subsection{Sudan}

The division of South Sudan caused a lot of economic shock, lost more than half of the Sudanese government's revenue and $95 \%$ of its exports. Economic growth slowed and led to an increase in consumer prices to $35 \%$, combined with rising fuel prices, sparking violent protests in September 2013. Continuous food prices were also a major cause of protests that began in December 2018. According to the World Bank the country moved from a low-income economy to a middle-income economy. In general, Sudan faces a low level of economic development as GDP declined to 2.6 in 2019. According to UNDP-HDR (2019) Sudan is still ranked among the lowest developing countries and the lowest developing countries in terms of HDI (0.507), as ranked 168th out of 189 countries. Sudanese economy reflected in low GDP per capita (\$1855), with high levels of poverty

According to the Sudan Central Bureau of Statistics and Ministry of Finance and Economic Planning (2019), by 2019 about 65 percent of Sudan's population is living below the poverty line which below US $\$ 1$ a day, more than half of Sudanese people suffer from extreme poverty. Sudan still tolerates political instability, lack of good governance and sensible institutions. The fact that only one party (the National Congress Party (NCP)) blocked the existence of a multi-party system and remained in full control for almost three decades (1989-2019) hampered any economic development.

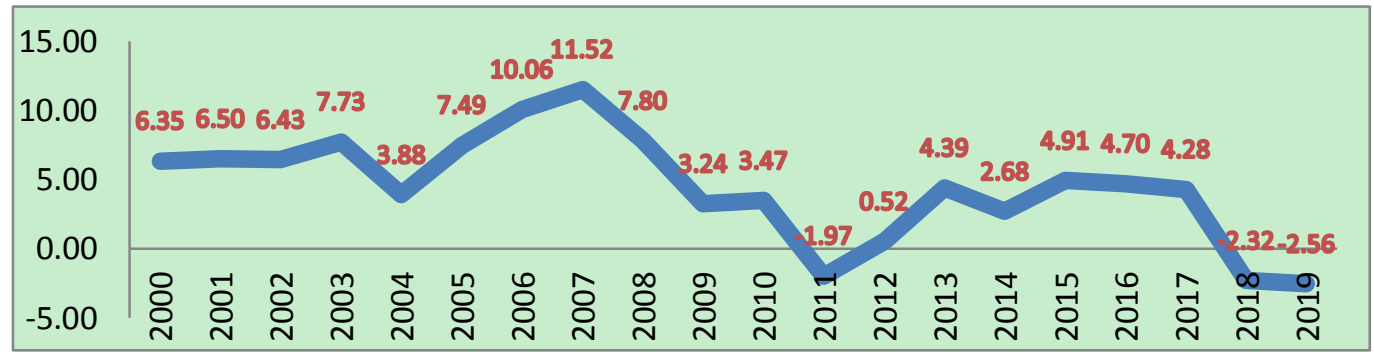

Figure 3. GDP annual growth rate in Sudan during the period (2000-2019) (\%)

Source: World development indicators, 2019.

\subsection{Indonesia}

Indonesia is considered the largest economy in Southeast Asia, the country has experienced impressive economic growth since overcoming the Asian financial crisis of the late 1990s. On the political side, Indonesia during 1960s was suffering from political instability and social unrest one million people at least was killed during the end of the president Sokarno and the end of the communist era in 1966 and the beginning of the era of president Suharto and his military coup on the previous president and the ruling party. 


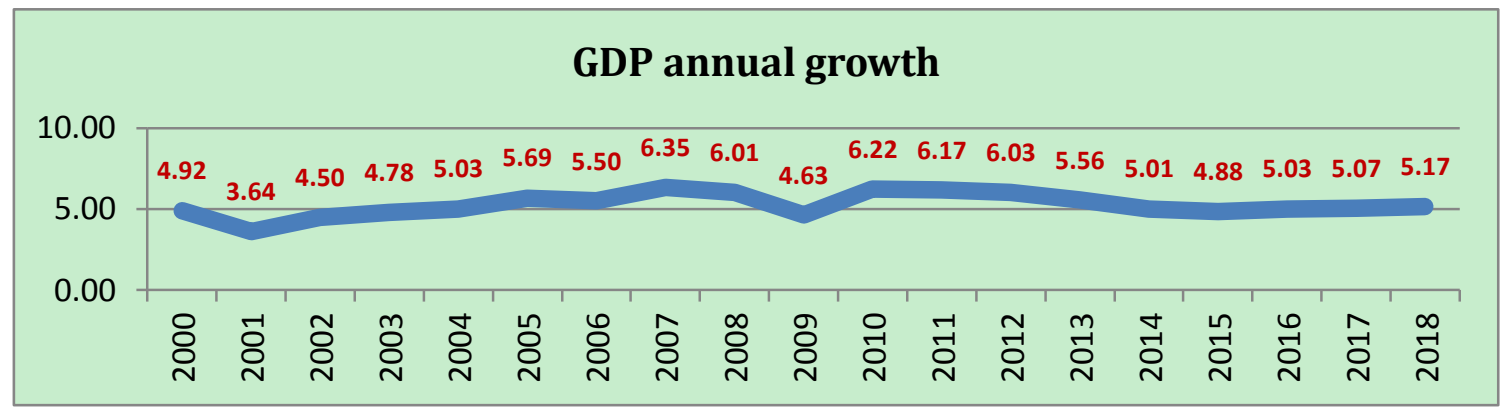

Figure 4. GDP Annual Growth Rate in Indonesia during the period (2000-2018)\%

Source: World development indicators, 2019.

\subsection{Turkey}

Since 2000 Turkey's economic performance has been impressive, leading to increased employment and incomes and making Turkey an upper-middle-income country (GDP per capita, current US\$ 9,140). The government programs have targeted vulnerable groups and disadvantaged regions. Poverty incidence more than halved over 2002-2015.

Turkey went through much political turbulence, in 1960, the Democratic Party was overthrown by a military coup, and Military rule was transitional and ended quickly after the adoption of a socially progressive constitution in 1961, which provided more checks and balances in the overall political process (Celâsun \& Rodrik, 1989). Starting from 1960, the economy was governed by five-year economic plans, between 1960 and 1972 were the years of rapid growth with the average growth rate of $6 \%$. However, the country faced serious economic problems between the years of 1970 - 1979 due to oil shock, Cyprus Operation and US embargo. The economy shifted from industrialization to export with lower value added to provide foreign currency. At the beginning of 1990s, public debts have reached at the dangerous levels and in 1994 economic crisis has been occurred. After the 1994 crisis, save the day interventions and debts received from the IMF. However, in the beginning of the 2000s two crises have been burst on November 2000 and on February 2001.

By the end of 2002 Turkey's economy has been shaped by the policies of the Justice and Development Party (AKP). Turkey's GDP has been increased by around 3.5 times and per capita income has been increased by around 3 times in fourteen years. However, external debt increased by more than $300 \%$, and public sector's debt increased by around \%2000 between 2002 and 2016.indeeed, there have been periods of high growth, but have not been sustainable. Periods of high growth were followed by periodic economic crises. Graph (5) illustrates the volatile nature of economic growth in Turkey.

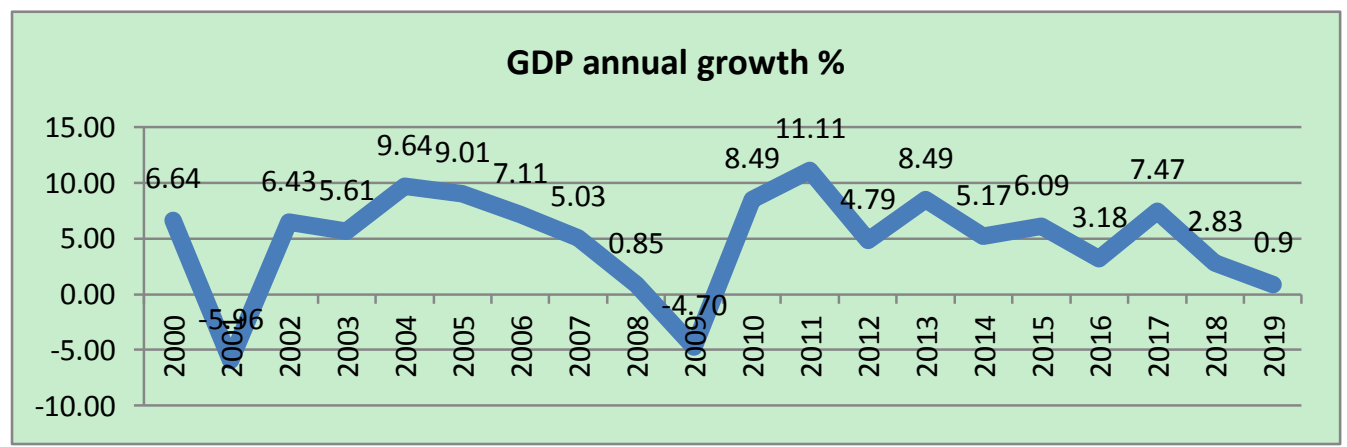

Figure 5. GDP Annual Growth Rate in Turkey during the Period (2000-2019)\%

Source: World development indicators, 2019.

\subsection{Brazil}

Brazil's economic history is full of economic changes. Brazil's economic history can be seen as a bombshell and 
busts. Brazil became independent in 1822, in 1930 they embarked on a series of important changes to modernization and its transformation into an industrialized state. From 1947 to 1992 the country's GDP decreased from 28\% to 11\% (Rassol 2014). At the same time in almost 50 years the GDP of the Brazilian sector has risen from less than $20 \%$ to $39 \%$. The entire policy framework since the 1990s has had a "Tripod" of a fixed inflation rate, a floating exchange rate and a major target for major budget failures.

In fact, Brazil has faced what Webster and Adler (1999) call a 'double revolution': democracy is about rebuilding the economy as the newly elected governments are roaming for integration into a competitive global economy. Some analysts emphasize Brazil's successful transformation of industrial strategies, others argue that Brazil's success in reducing poverty levels is a 'conditional transfer of funds', or a payment to the country's poor.

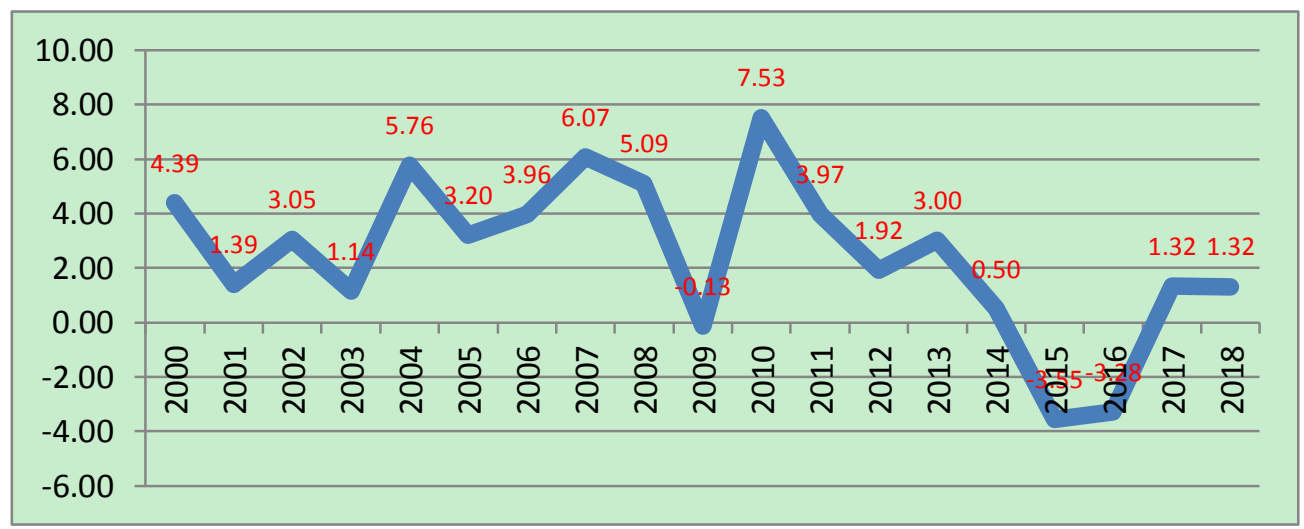

Figure 6. GDP annual growth rate in Brazil during the period (2000-2018) (\%)

Source: World development indicators, 2019

\subsection{Egypt}

Egypt is one of the Arab spring countries, the country has experienced two economic reforms with IMF, and the first one was on 1990, while the second one was in 2016. Egypt's economic growth is characterized with highly volatile as shown in figure (7) Egypt was always very vulnerable to external shocks. Since January 2011, the starting of revolution in Egypt, the economy went through many turmoil. The economic situation of poor people were one of the main factors that drove people into the streets in 2013. Since then the country facing many challenges concerning the economic security. Since the January 25 Revolution there have been eight cabinet changes during the period 20112014, a number equal to that of the entire period 1981-2010. (Abdelkader, 2017)

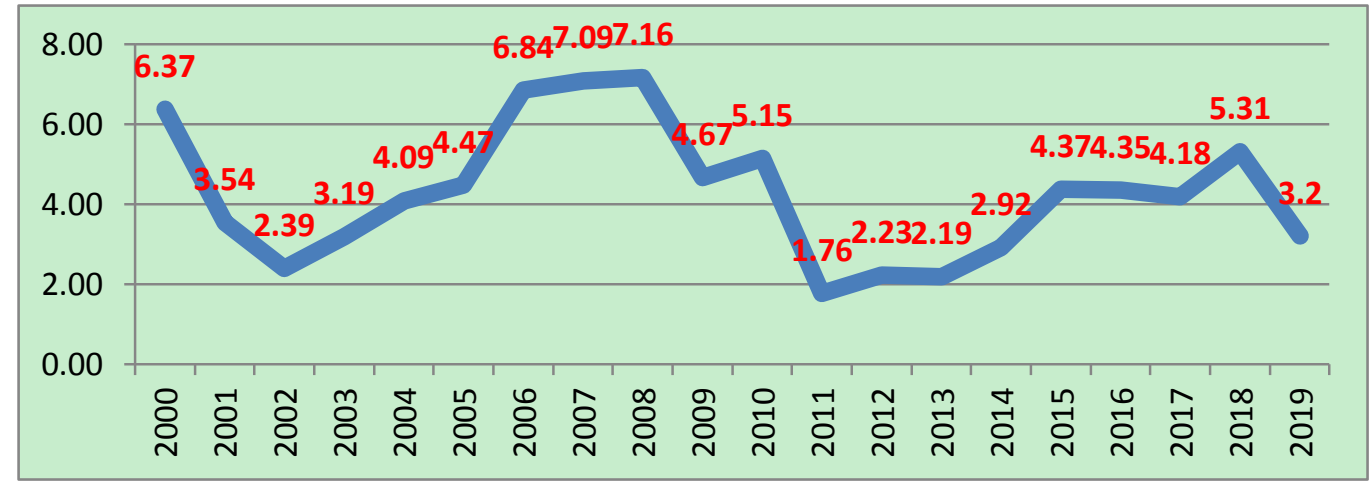

Figure 7. GDP annual growth rate in Egypt during the period (2000-2019) (\%)

Source: World development indicators, 2019. 


\section{Data and Methodology}

\subsection{Panel Unit Root Test}

To investigate the stationarity of the variables the paper will conduct panel unit root tests. There are some approaches that analyze unit roots such as: PP - Fisher Chi-square, Pesaran and Shin, Levin, Lin \& Chu Breitung $\mathrm{t}$-stat and ADF for the benefit of variables.

\subsection{Panel Co-integration Test}

In general, if one or more of them is non-stationary, then their linear combination will also be non-stationary, and the degree of integration of the combination will be equal to that of the most highly integrated series. The aim of this paper is to investigate the relationship between the variables in the long run and short run using Cointegration analysis, and error correction model. First, we examine based on cointegration analysis the long run unbiasedness and efficiency. Second, examining the short run unbiasedness and efficiency based on an error correction model (ECM).

\subsection{Empirical Model}

According to Abeyasinghe (2004) and Fethi (2007) they have used the model below to examine the effect of political instability on economic growth for both short run and long run periods. The model is as follows:

$$
\begin{gathered}
R G D P t=\beta_{0}+\beta_{1} G F C_{t}+\beta_{2} \mathrm{HDI}_{t}+\beta_{3} P S_{t} \\
\Delta L R \mathrm{GDP}_{\mathrm{t}}=\beta_{0}+E C T(-1)+\beta_{1} \Delta \mathrm{GFC}_{\mathrm{t}}+\beta_{2} \Delta \mathrm{HDI}_{\mathrm{t}}+\beta_{3} \Delta \mathrm{PS}_{\mathrm{t}}+\mathrm{u}_{\mathrm{t}}
\end{gathered}
$$

Where,

RGDP is GDP growth,

GFC is gross fixed capital formation as a proxy variable for capital,

HDI is the human development index which provides a measure of human development consisting of three dimensions: living a long and healthy life (measured by life expectancy), being educated (measured by adult literacy and enrolment at the primary, secondary and tertiary level) and having a decent standard of living (measured by purchasing power parity, PPP, income level). to reflect the level of welfare and political and economic stability in each country.

PS is political instability variable which measures the absence of violence, terrorism measures perception of the possibilities of political instability it uses different individual variables as armed conflict, social unrest, terrorist threat, etc.....

$\Delta$ is defined as difference and ECT is the error correction term.

\subsection{Descriptive Statistics}

Table (1) in the appendix presents the descriptive statistics for the research variables. The results show that the mean and the median of the GDP growth rate is $3.95 \%$ and $4.37 \%$, respectively. The minimum value of GDP growth rate equal $-13.1267 \%$ and the maximum value is $11.52 \%$. Also, the mean and the median of Gross Capital formation is $24.047,23.278$, respectively, with a minimum value of 5.53 and a maximum value of 50.78 . The mean and the median of HDI is $0.626,0.643$, respectively with a minimum value of 0.332 and a maximum value of 0.807 . Also, the mean and the median of Political instability is $-0.97,-0.94$, respectively with a minimum value of -2.67 and a maximum value of 0.81 . From the value of the p-value of Jarque-Bera test it is clear that all variables are not normally distributed this with confident $95 \%$ as the p-values for all variables are less than $5 \%$.

\section{Empirical Results}

\subsection{Analyses of Unit Root Test}

The panel unit root test is conducted and this according to PP - Fisher Chi-square, Im, Pesaran and Shin W-stat, Levin, Lin \& Chu Breitung t-stat and ADF - Fisher Chi-square approaches and the results are shown in tables from (2) till table (8). From these tables, it is clear that GPD growth rate is stationary at its level as p-values for all tests are less than $5 \%$, this mean that the null hypothesis of the unit root is rejected at 95\% confident and this for GDP growth at its level. While each of gross capital formation, HDI, and political instability are not stationary at their levels, however, they became stationary after taking the first difference, and this with confidence $95 \%$. So, we can reach the result that the four variables are integrated of order one I (1). 


\subsection{Analyses of Co-integration Tests}

The Pedroni test is conducted to test the co- integration between the variables. For choosing the appropriate lag length several criterions can be applied. The appropriate lag length is one according to AIC, SC, FPE, and HQ criterion, as clear in Table (9) in the appendix.

Considering, 1 lag and considering also a constant in the cointegration relation, the results are showed in table (10). In this table we have cointegration test outcomes for the selected countries from different continents. Pedroni (Engel-Granger based), Kao (Engel-Granger based), and Fisher (combined Johansen based) tests are usually applied as cointegration tests. According to table (10), we can reject single null hypothesis of no integration and this with confident $95 \%$, as most of p-values are less than $5 \%$.

In the level form equation capital and HDI are statistically significant and have positive influence on economic growth in the long run with confidence level 95\%, as p-value associated for theses variables are less than 5\%. While political instability is statistically significant and have negative influence on economic growth during the long run period with confidence level $95 \%$, as p-value associated for this is less than $5 \%$. This means that $1 \%$ change in gross capital formation causes $0.0288 \%$ rise in economic growth. Also, one percent change in HDI causes $2.86 \%$ increase in economic growth, and $1 \%$ change in political instability causes $0.17 \%$ reduction in economic growth.

\subsection{Vector Error Correction Model}

In error correction model, the term of error correction is statistically significant at $5 \%(-0.6897)$, it is negative and has reasonable score. ECT shows that $68.98 \%$ of distinction between short-term and long-term equilibrium is eliminated annually these results are depicted in table (11) in the appendix. Therefore, disequilibrium in economic growth encounter equilibrium at normal levels. Short-term coefficient of capital growth is statistically significant at lag 1 at $5 \%$. This shows positive short-term movements. When capital rises for $1 \%$, economic growth rises for $0.0217 \%$ at lag 1 . Also, Short-term coefficients of HDI are statistically significant at lag 1 at 5\%. This shows positive short-term movements. When HDI rises for 1\%, economic growth rises for $47 \%$ at lag 1 . Political instability is statistically significant as a short-term coefficient and is statistically significant at $5 \%$ level at lag 1 . This indicates negative short-term movements. When political instability increases for one percent, economic growth decreases for $0.521 \%$ at lag 1 . So, we can reach the conclusion that there is a statistically significant relation between political instability and economic growth in the selected countries during the study period.

\section{Conclusion}

This study focused on the relationship between economic growth and political instability of seven selected countries characterized by either Arab spring countries or has a long history of political instability, they also have common characteristics as they are developing, middle income or low-income countries. In our model, capital and HDI are statistically significant and have positive influence on economic growth in the long run with confidence level 95\%. While political instability is statistically significant and have negative influence on economic growth during the long run period with confidence level $95 \%$. This means that $1 \%$ change in gross capital formation causes $0.0288 \%$ rise in economic growth. Also, one percent increase in HDI causes $2.86 \%$ increase in economic growth, and $1 \%$ change in political instability causes $0.17 \%$ reduction in economic growth.

Results convey that political instability in these countries has a negative impact on economic growth, through the main channels which are HDI and investment. to maintain sustainable economic development, countries should widen their focus from only economic variables to include also political and institutional variables that affect economic growth. As a conclusion, the policymakers could enhance and improve the economic growth by decreasing the negative impact of political instability and its causes and reasons.

\section{References}

Abdelkader, H. E. M. (2017). Political instability and economic growth in Egypt. Review of Middle East Economics and Finance, 13(2). https://doi.org/10.1515/rmeef-2017-0019

Aisen, A., \& Veiga, F. J. (2013). How does political instability affect economic growth?. European Journal of Political Economy, 29, 151-167. https://doi.org/10.1016/j.ejpoleco.2012.11.001

Alberto, A., et al.. (1996). Political instability and economic growth. Journal of Economic Growth, 1(2). https://doi.org/10.1007/BF00138862 
Alesina, A., \& Perotti, R. (1996). Income distribution, political instability, and investment. European Economic Review, 40(6), 1203-1228. https://doi.org/10.1016/0014-2921(95)00030-5

Alesina, A., \& Rodrik, D. (1991). Distributive politics and economic growth. National Bureau of Economic Reserach, 3668, 1203-1228. https://doi.org/10.3386/w3668

Alesina, A., \& Rodrik, D. (1994). Distributive politics and economic growth. The Quarterly Journal of Economics, 109(2), 465-490. https://doi.org/10.2307/2118470

Alesina, A., \& Tabellini, G. (1989). External debt, capital flight and political risk. Journal of International Economics, 27(3-4), 199-220. https://doi.org/10.1016/0022-1996(89)90052-4

Alesina, A., \& Tabellini, G. (1990). A positive theory of fiscal deficits and government debt. The Review of Economic Studies, 57(3), 403-414. https://doi.org/10.2307/2298021

Alesina, A., Grilli, V., \& Milesi-Ferrett, G. M. (1993). The political economy of capital controls (No. w4353). National Bureau of Economic Research. https://doi.org/10.3386/w4353

Alesina, A., Londregan, J., \& Rosenthal, H. (1990). A Model of the Political Economy of the United States' NBER. Working Paper No. 3611. https://doi.org/10.3386/w3611

Alesina, A., Ozler, S., Roubini, N., \& Swagel, P. (1996). Political instability and economic growth. Journal of Economic Growth, 1, 189-211. https://doi.org/10.1007/BF00138862

Alfaro, L., Kalemli-Ozcan, S., \& Volosovych, V. (2008). Why doesn't capital flow from rich to poor countries? An empirical investigation. The Review of Economics and Statistics, 90(2), 347-368. https://doi.org/10.1162/rest.90.2.347

Barro, R. J. (1991). Economic growth in a cross section of countries. The Quarterly Journal of Economics, 106(2), 407-443. https://doi.org/10.2307/2937943

Barro, R. J., \& Lee, J. W. (1994, June). Sources of economic growth. In Carnegie-Rochester conference series on public policy (Vol. 40, pp. 1-46). North-Holland. https://doi.org/10.1016/0167-2231(94)90002-7

Ben Romdhane, M. (2006). Social policy and development in Tunisia since independence, a political perspective. Social Policy in the Middle East: Political, Economics and Gender Dynamics, Palgrave Macmillan.

Benhabib, J., \& Rustichini, A. (1996). Social conflict and growth. Journal of Economic Growth, 1(1), 125-142. https://doi.org/10.1007/BF00163345

Bernal-Verdugo, L. E., Furceri, D., \& Guillaume, D. M. (2013). IMF Working Paper. Washington, D. C: Research Department. International Monetary.

Blavier, P. (2013). Hibou (Béatrice), La force de l'obéissance. Économie politique de la répression en Tunisie, Paris, La Découverte, 2006, 365 pages \& Hibou (Béatrice), Anatomie politique de la domination, Paris, La Découverte, 2011, 298 pages. Politix, (2), 213-218. https://doi.org/10.3917/pox.102.0213

Blomberg, S. B. (1996). Growth, political instability and the defence burden. Economica, 649-672. https://doi.org/10.2307/2555001

Busse, M., \& Hefeker, C. (2007). Political risk, institutions and foreign direct investment. European Journal of Political Economy, 23(2), 397-415. https://doi.org/10.1016/j.ejpoleco.2006.02.003

Chawdhury, J. (2016). Political instability a major obstacle to economic growth in Bangladesh. Master thesis, business management, Centria University of Applied Sciences, dec.

Compton, R. A., Giedeman, D. C., \& Johnson, N. D. (2006). Political instability, institutions, and economic growth. In preliminary draft presented at XIV International Economic History Congress, Helsinki, May. Retrieved from http://www.helsinki.fi/iehc2006/papers3/Giedeman.pdf

Cukierman, A., Edwards, S., \& Tabellini, G. (1989). Seigniorage and political instability (No. w3199). National Bureau of Economic Research. https://doi.org/10.3386/w3199

Fosu, A. K. (1992). Political instability and economic growth: evidence from Sub-Saharan Africa. Economic Development and Cultural Change, 40(4), 829-841. https://doi.org/10.1086/451979

Godec, R. F. (2010). Corruption en Tunisie: Ce qui est à toi m'appartient. Tunisia Watch, 14.

Goodrich, S. (1992). Political Instability as a Determinant of U.S. Foreign Direct Investments. Harvard University Senior Thesis. 
Granger, C. W. (1966). The typical spectral shape of an economic variable. Econometrica: Journal of the Econometric Society, 150-161. https://doi.org/10.2307/1909859

Granger, C. W., Newbold, P., \& Econom, J. (1974). Spurious regressions in econometrics. A Companion of Theoretical Econometrics, 557-61. https://doi.org/10.1016/0304-4076(74)90034-7

Grossman, H. I. (1991). A general equilibrium model of insurrections. The American Economic Review, 81(4).

Gupta, D. K. (1990). The economics of political violence: The effect of political instability on economic growth. Praeger.

Gurgul, H., \& Lach, Ł. (2013). Political instability and economic growth: Evidence from two decades of transition in CEE. Communist and Post-Communist https://doi.org/10.1016/j.postcomstud.2013.03.008

Gyimah-Brempong, K., \& Dapaah, A. S. (1996). Non elite political instability and economic growth: Evidence from Sub-Saharan Africa. Journal of Economic Development, 21(1), 181-210.

International Monetary Fund (IMF). (n.d.). The dynamic effect of social and political instability on output: the role of reforms.

Jong-A-Pin, R. (2009). On the measurement of political instability and its impact on economic growth. European Journal of Political Economy, 25(1), 15-29. https://doi.org/10.1016/j.ejpoleco.2008.09.010

Londregan, J. B., \& Poole, K. T. (1990). Poverty, the coup trap, and the seizure of executive power. World Politics: A Quarterly Journal of International Relations, 151-183. https://doi.org/10.2307/2010462

Londregan, J., \& Poole, K. (1992). The seizure of executive power and economic growth: some additional evidence. Political Economy, Growth, and Business Cycles, 51-79.

Murphy, K. M., Shleifer, A., \& Vishny, R. W. (1991). The allocation of talent: Implications for growth. The Quarterly Journal of Economics, 106(2), 503-530. https://doi.org/10.2307/2937945

Özler, S., \& Rodrik, D. (1992). External shocks, politics and private investment: Some theory and empirical evidence. Journal of Development Economics, 39(1), 141-162. https://doi.org/10.1016/0304-3878(92)90060-M

Ozler, S., \& Tabellini, G. (1991). External debt and political instability (No. w3772). National Bureau of Economic Research. https://doi.org/10.3386/w3772

Przeworski, A., \& Limongi, F. (1993). Political regimes and economic growth. Journal of Economic Perspectives, 7(3), 51-69. https://doi.org/10.1257/jep.7.3.51

Qureshi, M. N., Ali, K., \& Khan, I. R. (2010). Political instability and economic development: Pakistan time-series analysis. International Research Journal of Finance and Economics, 56, 179-192.

Rahman, R., \& Rashid, M. M. (2018). Political instability and economic growth in Bangladesh. Peer-Reviewed Academic Journal Innovative Issues and Approaches in Social Sciences. https://doi.org/10.12959/issn.1855-0541.IIASS-2018-no2-art5

Rashid, M. (2018). Political instability and economic growth in Bangladesh. Innovative Issues and Approaches in Social Sciences, 11(2). https://doi.org/10.12959/issn.1855-0541.IIASS-2018-no2-art5

Rodrik, D. (1991). Policy uncertainty and private investment in developing countries. Journal of Development Economics, 36, 229-242. https://doi.org/10.1016/0304-3878(91)90034-S

Shahabad, R. D. (2014). The impacts of political stability on economic growth: Evidence from panel data analysis. Master's thesis, Eastern Mediterranean University (EMU)-Doğu Akdeniz Üniversitesi (DAÜ).

Sürmeli, A. S. (2017). Political instability and economic growth in Turkey. Doctoral dissertation, İstanbul Bilgi Ünversitesi.

Sweidan, O. D. (2016). Political instability and economic growth: evidence from Jordan. Review of Middle East Economics and Finance, 12(3), 279-300. https://doi.org/10.1515/rmeef-2015-0025

Webster, E., \& Adler, G. (1999). Toward a class compromise in South Africa's "double transition": Bargained liberalization and the consolidation of democracy. Politics \& Society, 27(3), 347-385. https://doi.org/10.1177/0032329299027003003

World Bank. (2019). World Development Indicators (WDI). Washington, D. C.: The World Bank 2019. 


\section{Appendix}
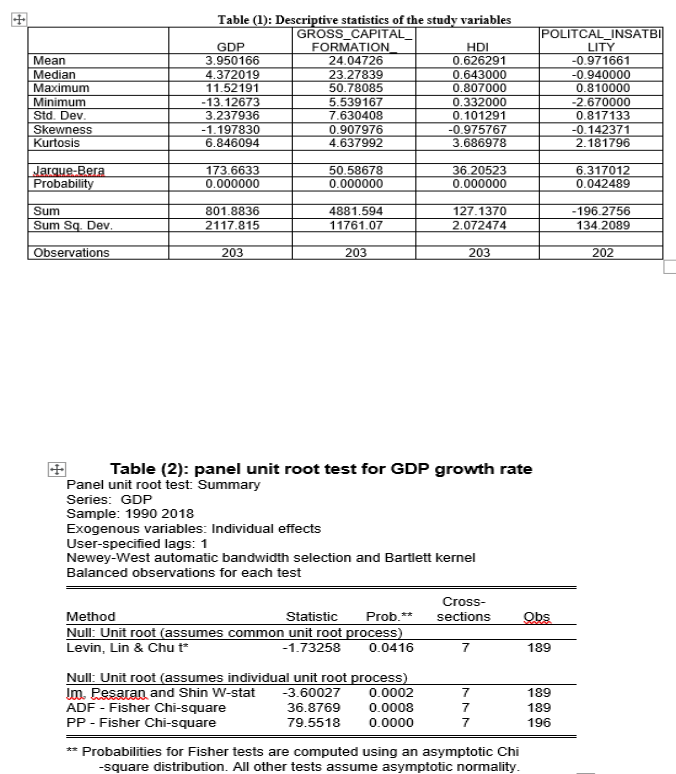

Table (3): panel unit root test for Gross capital formation. Panel unit root test: Summary
Series: GROSS_CAPITAL_FORMATION_

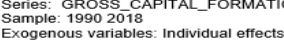
Exagenous variables: Individual effect Newey-West automatic bandwidth selection and Bartlett kernel Balanced observations for each test Method $\quad$ Statistic Prob.** $\begin{gathered}\text { Cross- } \\ \text { sections }\end{gathered}$ \begin{tabular}{llccc} 
& Statistic & Prob.** & sections & Qbs \\
\hline Method & & \\
\hline Null Unit root (assumes comman unit root process) & 0.03445 & 0.5137 & 7 & 189
\end{tabular} \begin{tabular}{lllll} 
Null: Unit root (assumes individual unit root process) \\
\hline Imo Ressaran and Shin W-Stat & 0.17664 & 0.5701 & 7 & 189 \\
\hline
\end{tabular} \begin{tabular}{lllll} 
Jm. Resaram and Shin W-stat & 0.17664 & 0.5701 & 7 & 189 \\
ADF - Fisher Chi-square & 10.9261 & 0.6918 & 7 & 189 \\
PP - Fisher Chi-square & 18.7635 & 0.1742 & 7 & 196 \\
\hline \hline
\end{tabular} * Probabilities for Fisher tests are computed using an asymptotic Chi
-square distribution. All other tests assume asymptotic normality.

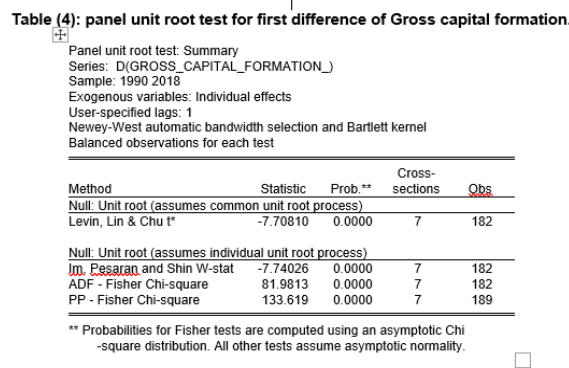



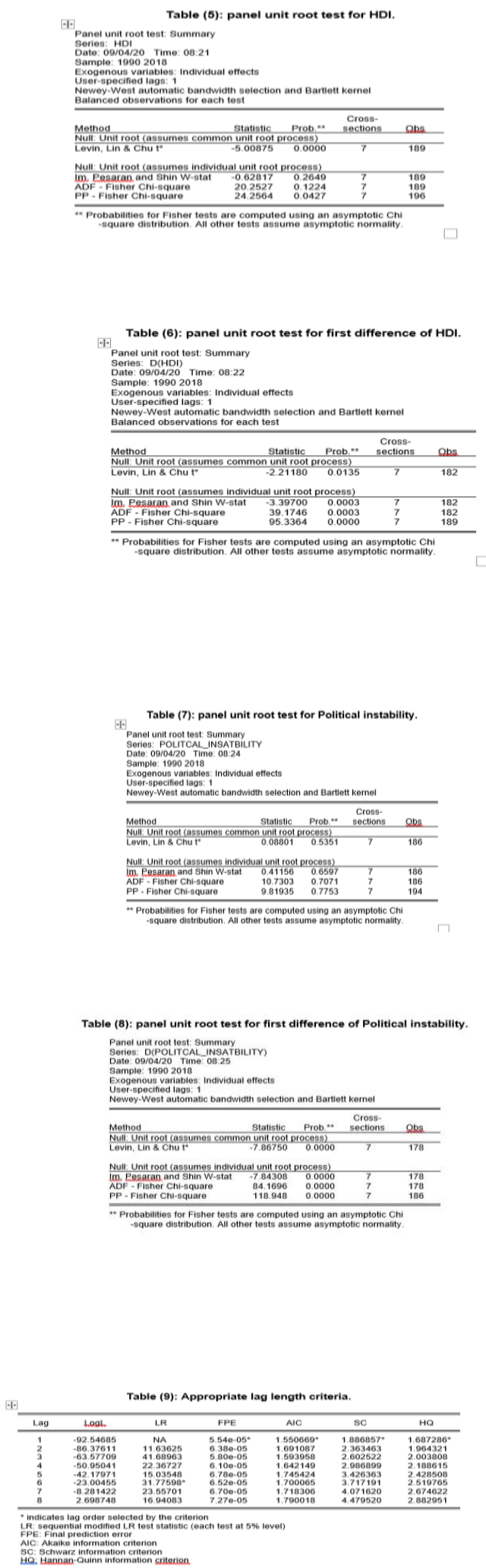
Table (10): Panel cointegration test.

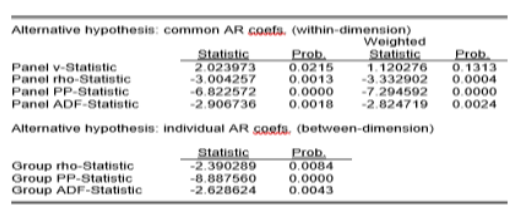

Table (11): Long-run relationship.
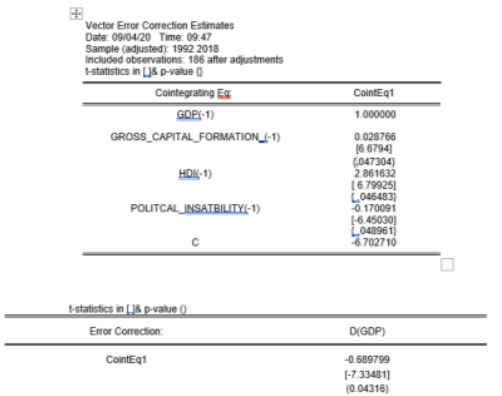

D(GOPS-1)

0.006374
77239707
$(0.06967)$

D(GROS__CAPITLLFORUATIONL-1)

0.021737
$[822127$
$[0.032991)$

DAOH-1)

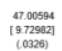

D(POUTCAL INSATBUTY(-1)

$-0.521362$

\begin{tabular}{|c|c|}
\hline R.-squared & 0.381348 \\
\hline Aig Risquared & 0.364164 \\
\hline 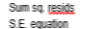 & 1631.931 \\
\hline $\begin{array}{l}\text { SE Eq vquaton } \\
\text { F-statescic }\end{array}$ & 3.011027 \\
\hline 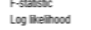 & $\begin{array}{l}22191071 \\
-4656974\end{array}$ \\
\hline Fhabe AlC & 5.0741606 \\
\hline Schlwarn SC & 5.178222 \\
\hline Mean dependent & $\begin{aligned}-0.0042626 \\
777506\end{aligned}$ \\
\hline
\end{tabular}

\section{Copyrights}

Copyright for this article is retained by the author(s), with first publication rights granted to the journal.

This is an open-access article distributed under the terms and conditions of the Creative Commons Attribution license (http://creativecommons.org/licenses/by/4.0/). 